Check for updates

New Delhi

Cite this as: BMJ 2020;370:m3422 http://dx.doi.org/10.1136/bmj.m3422 Published: 02 September 2020

\section{Covid-19: India should abandon lockdown and refocus its testing policy, say public health specialists}

\author{
India Correspondent BMJ
}

Public health specialists in India have called on the government to adopt a more pragmatic approach to testing for covid-19, amid evidence of widespread prevalence of infection.

Lockdown in India should be discontinued, said a joint statement from the Indian Public Health Association, the Indian Association of Epidemiologists, and the Indian Association of Social and Preventive Medicine. ${ }^{1}$ And local restrictions on movement and mingling should be imposed only where there is mild or limited spread of SARS-Cov-2 and only after the effects on the livelihood of target populations have been assessed, they advised.

India imposed a nationwide lockdown in March that has been relaxed in phases, but several states and cities continue to impose local lockdowns, including closing all establishments at nights and weekends. The country's current testing policy aims to track and test all contacts of at least $80 \%$ of new covid cases, which last week averaged 76000 a day.

The public health experts want the government to abandon its current approach, which they say is impractical and wasteful because it cannot detect most infections. Instead they recommend "targeted testing," of people with symptoms and of high risk groups such as healthcare workers, elderly people, and surgical patients.

They said that the current track and test policy had detected less than $5 \%$ of estimated infections, while antibody surveys had indicated a much larger epidemic. Delhi, for instance, with an estimated population of 20 million, has recorded 177000 cases, but an unpublished survey by the Delhi government released last month found antibodies in $29 \%$ of the sampled population. A similar survey in Mumbai has recorded antibody prevalence as high as $58 \%$ in urban slums and $15 \%$ in non-slum localities. ${ }^{2}$ )

\section{Cases and deaths}

India has recorded over 3.76 million cases of covid-19, and on 2 September over 800 ooo patients were under medical supervision, the largest number in the world after the US. And more than 66 ooo patients have died-the third highest figure in the world, with India set to overtake Brazil in a week and the US in about two months, said analysts.

Sanjay Rai, professor of community medicine at the All India Institute of Medical Sciences in New Delhi and president of the Indian Public Health Association, told The BMJ, "When we have such widespread and undetected transmission, the strategy has to change."

However, government officials believe that India's declining case fatality rate among covid patients reflects the country's effective response to the epidemic. India's case fatality rate has fallen from $3.3 \%$ in mid-June to $2.7 \%$ in mid-July and then to $1.76 \%$ on 2 September. Health officials have attributed this reduction to expanded testing, early diagnosis, and effective clinical management with standard treatment protocols.

Only $0.28 \%$ of patients were receiving ventilator support and $1.92 \%$ were in intensive care units, India's health ministry said last month. But some analysts are concerned about how India's rural areas will cope when their numbers of infections grow. Healthcare facilities serving rural populations in many states lack the infrastructure and expertise to manage severe covid cases.

Shahid Jameel, a senior virologist and chief executive officer of the Wellcome Trust DBT India Alliance, a UK-India research partnership, told The BMJ, "The outbreak has shifted from the metros to smaller towns and villages: this is likely to make it even more difficult to control.”

Some states have augmented their ambulance services in rural areas to help transfer patients to covid hospitals in district headquarters or cities. But Oomen John, a physician and senior research fellow at the George Institute for Global Health in New Delhi, told The BMJ, "Staff in rural healthcare facilities would need to be trained to recognise hypoxia early. A strong training programme on triage and referrals would be critical."

1 Indian Public Health Association, Indian Association of Epidemiologists, Indian Association of Social and Preventive Medicine. 3rd joint statement on covid-19 pandemic in India-public health approach for covid-19 control. 25 Aug 2020. https://www.iphaonline.org/wp-content/uploads/2020/08/3rd-Joint-Statementof-IPHA-IAPSM-and-IAE-for-COVID-19-containment-plan_August-25-2020.pdf.

2 Malani A, Shah D, Kang G, et al. Seroprevalence of SARS-CoV-2 in slums and non-slums of Mumbai, India, during June 29-July 19, 2020. medRxiv 2020 Sep 1 (preprint). https://www.medrxiv.org/content/10.1101/2020.08.27.20182741v1.full.pdf.

This article is made freely available for use in accordance with BMJ's website terms and conditions for the duration of the covid-19 pandemic or until otherwise determined by BMJ. You may use, download and print the article for any lawful, non-commercial purpose (including text and data mining) provided that all copyright notices and trade marks are retained. 